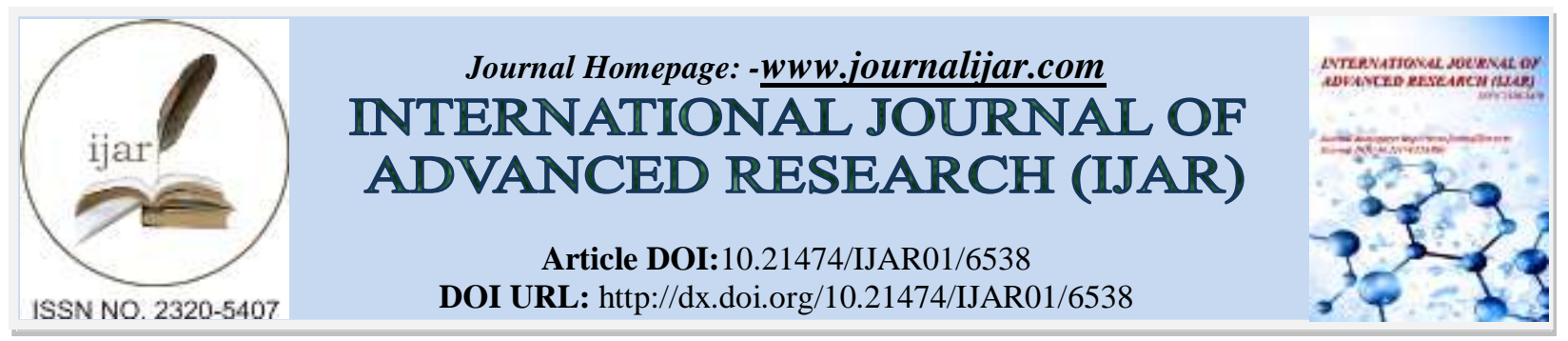

RESEARCH ARTICLE

\title{
FORMULATION AND EVALUATION OF TRANSDERMAL DRUG DELIVERY SYSTEM CONTAINING ANTI-INFLAMMATORY AGENT.
}

\author{
K.D Mali, N.L. Patil, T.K. Patil, S.D. Raysing and Dr. S.J. Surana.
}

\section{Manuscript Info}

(.........................

Manuscript History

Received: 15 December 2017

Final Accepted: 17 January 2018

Published: February 2018

\section{Keywords:-}

Lornoxicam, Transdermal patch, physical characterization, in vitro release study, stability study.

\section{Abstract}

Aim of the present study was to develop site-specific drug delivery system of lornoxicam for the treatment of arthritis, pain etc., which has excellent activity on inhibition of Cyclooxygenase-1 and Cyclooxygenase-2 enzymes. The formulations were developed by utilizing variouspolymers such as hydroxy propyl methyl cellulose and Eudragit RL-100 by solvent casting technique by the use of plasticizer (PEG-400 \& DBT). The calibration curve of lornoxicam was developed in methanol/water. Compatibility study was carried out by FT-IR and Differential scanning colorimetry. The formulations were evaluated for thickness, folding endurance, weight variation, drug content, percent moisture loss, tensile strength. In vitro drug release study was also carried out by using PBS pH 7.4 and the samples were analyzed UVspectrophotometrically at $374 \mathrm{~nm}$. FT-IR and DSC study revealed no interaction between drug and polymers. Formulations shown good uniformity of drug content, there was no any kind of effect on moisture loss test. Formulations showed thickness within the range of (0.072 to 0.119). Formulation F1, F2, F5 \& F6 showed good tensile strength. By increasing the concentration of Eudragit RL-100 in the formulation tensile strength, and folding endurance increases. Formulation F6 shows the release of drug $96.74 \%$ at the end of $12 \mathrm{~h}$ and was considered as a best formulation. A short-term stability study of the optimized formulation (F6) was also carried out at $40^{\circ} \mathrm{C}$ for three months. At periodic interval $0,30,60$, and 90 days a known quantity of sample was withdrawn and then analyzed for drug content and in vitro drug release studies, results showed a good content of uniformity and 95.23\% release was observed at the end of 90 days. After a short-term stability study, there was no or very little amount of degradation was observed.

\section{Introduction:-}

Rheumatic disease is one of the commonest inflammatory conditions in the developing countries and is a common cause of the disability. Analgesics and non-steroidal anti-inflammatory drugs (NSAIDs) have been widely used in the treatment of rheumatoid arthritis and other related conditions in a conventional drug therapy. Lornoxicam (LOR) is a newer and highly potent NSAID that inhibits the prostaglandin Synthesis and act as a useful agent to control inflammatory conditions ${ }^{1}$. 
In the treatment of rheumatoid diseases, patients are advised to be on prolonged medicationof LOR. Delivery of drug by predetermined amount to the intact skin at a predetermined rate done by transdermal drug delivery systems. The transdermal drug delivery has gained importance in recent years, as it maintaining constant blood levels for longer period resulting in a reduction of dosing frequency, improved bioavailability, hepatic first pass metabolism, decreased gastrointestinal irritation that occurs due to local contact with gastric mucosa and improved patient compliance $^{2}$.

Hence, TDDS of LOR was considered as an ideal method tominimize side effects of LOR and to improve patient complianceAdditionally, LOR in the form of TDDS will be very usefull to supplymedication systemically as well as locally to the affected tissue (painful joints).

The need of the present investigation is to formulate matrix type transdermal drug delivery system of a non-steroidal anti-inflammatory drug Lornoxicam using Hydroxy Propyl methyl Cellulose and Eudragit RL-100 as a release controlling polymers. The prepared patches were characterized by diffusion studies. The intention behind to choose the work was to develop the TDDS, which controls the release of Lornoxicam upto 12 hrs $^{3-5}$.

\section{Material And Method:-}

Lornoxicam was a gift sample obtained from Glenmark. Generics Pvt. Ltd, pune India. The polymers such as HPMC, Polyethylene glycol 400,obtained from Rankem chemicals Mumbai. Eudragit RL-100 obtained from Sigma life science,Mumbai. Sodium hydroxide, Di-butyl phthalate from Loba chemicals,Pvt Ltd Mumbai. Dimethyl sulphoxide(DMSO), Methanol, Dichloromethane obtained from Merk chemicals, Mumbai India All other chemicals were of analytical grade.

\section{Methods:-}

Solubility study:-

Solubility of LOR in water, 7.4 and 6.8 aqueous phosphate buffer was determined. Excess amount of LOR powder was added in conical flask containing $10 \mathrm{ml}$ of aqueous phosphate buffer. The suspension was briefly sonicated and agitated at $32{ }^{\circ} \mathrm{C}$ on water bath shaker at $300 \mathrm{rev}$. / min for 24 hours until equilibration. Aliquot was withdrawn and then filtrated through $0.45 \mu \mathrm{m}$ millipore filter and then diluted with solvent. The samples were analyzed by UVspectrophotometer to determine the concentration of drug at $\lambda \max 374 \mathrm{~nm}$ of LOR.

\section{Drug-Excipients compatibility Studies:-}

The drug-excipients compatibility study was carried out by using FTIR and DSC ${ }^{7,8}$.

\section{Infrared Spectroscopy:-}

FTIR spectra of plane drug lornoxicam and the mixture of polymers were taken to study the interaction between them. A mixture of lornoxicam with HPMC and Eudragit RL-100 were mixed separately with IR grade KBr in the ratio of 100:1 and compressed using motorized pellet press at 15 tonnes pressure.comparision study between the mixtures of drug with polymer.

\section{Differential Scanning calorimetry (DSC):-}

Firstly, melting point of drug was determine by capillary method then confirmed by DSC. Thermogram of lornoxicam was obtained using DSC. Drug-excipients compatibility study was performed by Differential Scanning calorimetry (DSC). Thermal analysis was performed using a differential scanning calorimetry (DSC) (MettlerToledo, Greifensee, Switzerland). The instrument was calibrated with indium. DSC thermograms were recorded for pure QUC, lipid-QUC physical mixture, and QUC-loaded NLCs. The samples, weighing 2 mg, were analysed in sealed and pin-holed standard $40 \mathrm{ll}$ aluminiumpans, with a heating rate of $10^{\circ} \mathrm{C} / \mathrm{min}$ from $30^{\circ} \mathrm{C}$ to $300^{\circ} \mathrm{C}$ and, during the measurement, the sample cell was continuously purged with nitrogen at a flow rate of $40 \mathrm{ml} / \mathrm{min}$

\section{Formulation Of Transdermal Patch ${ }^{9}:-$}

TDDS composed of different ratios of HPMC and Eudragit RL-100 containing LOR. Transdermal patches containing LOR were prepared by the solvent casting method. The formulations of LOR were prepared using the polymer such HPMC and Eudragit RL-100 with the use of plasticizer PEG-400, Dibutylphthalate. HPMC was dissolved in a $5 \mathrm{ml}$ solvent of containing (Dichlomethane/methanol) (4:1) ratio by, which is previously dissolved by putting the solution on magnetic stirrer (Rpm 60/min). In another side, the Eudragit RL-100 is dissolved in a $5 \mathrm{ml}$ (Dichlomethane/methanol), then both solution added and mix throughout. The drug was dissolved added to the 
above polymer solution along with PEG-400, Dibutyl Phthalate, as plasticizer, and $0.2 \mathrm{ml}$ of DMSO as penetration enhancer,which is tho-roughly mixed on magnetic stirrer (Rpm 60/min) to form a homogeneous mixture. The volume was made up to $10-\mathrm{ml}$ and sonicated. The solution was poured on the mercury placed in a glass Petri dish of $36.29 \mathrm{~cm}^{2}$ area and dried at room temperature for $24 \mathrm{hr}$. Cut into the required size to deliver the equivalent dose $(2 \times$ $2 \mathrm{~cm}^{2}$ per patch) containing of $8 \mathrm{mg}$ of drug and samples were stored in a desiccators see table 1 and figure 1 .

Table 6:-Composition Of Different Formulations Containing Lor.

\begin{tabular}{|c|c|c|c|c|c|c|}
\hline Ingredients & F1 & F2 & F3 & F4 & F5 & F6 \\
\hline Drug (mg) & 72 & 72 & 72 & 72 & 72 & 72 \\
\hline $\begin{array}{c}\text { Hydroxy Propyl methyl } \\
\text { cellulose(mg) }\end{array}$ & 50 & 50 & 250 & 350 & 100 & 100 \\
\hline Eudragit RL-100 (mg) & 250 & 350 & 50 & 50 & 350 & 200 \\
\hline DMSO (ml) & 0.2 & 0.2 & 0.2 & 0.2 & 0.2 & 0.2 \\
\hline Dibutylphalate (ml) & $5 \%$ & - & $5 \%$ & - & $5 \%$ & - \\
\hline $\begin{array}{c}\text { PEG-400 (ml) } \\
\text { (\%/w of polymers) }\end{array}$ & - & $5 \%$ & - & $5 \%$ & $5 \%$ \\
\hline $\begin{array}{c}\text { Solvent(Dichloromethane: } \\
\text { Methanol )(4:1) (ml) }\end{array}$ & 10 & 10 & 10 & 10 & 10 & 10 \\
\hline
\end{tabular}

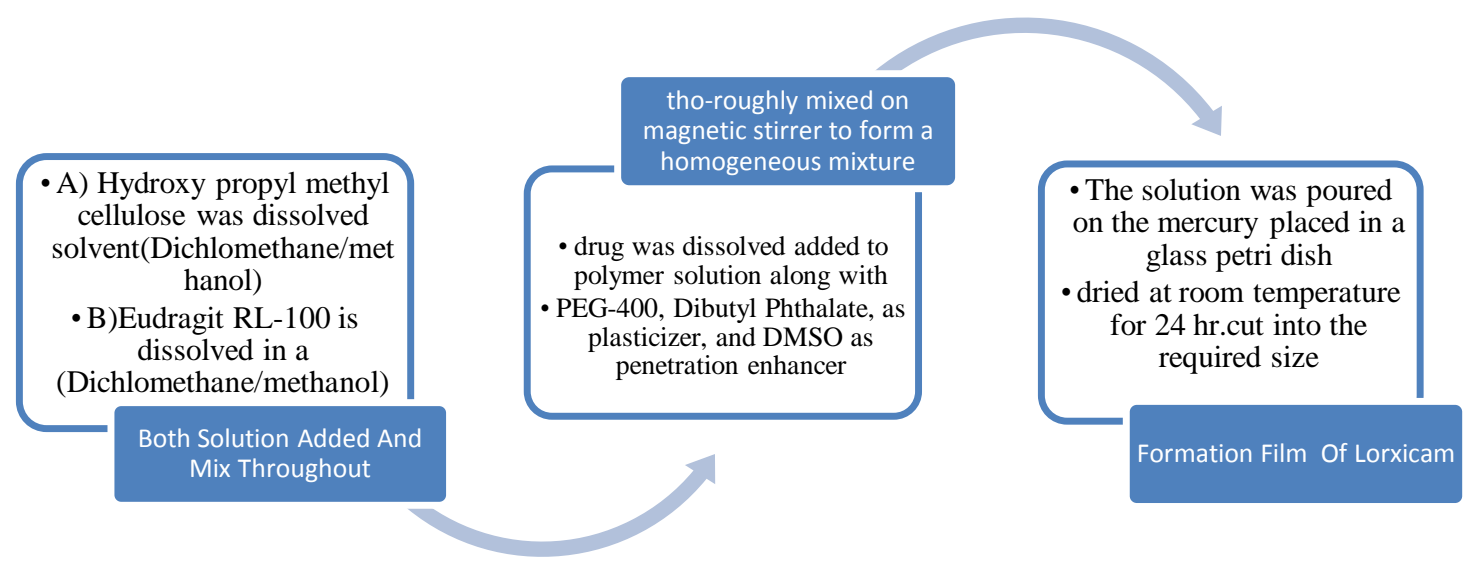

Fig. 1:-Formulation Process Of Transdermal Patches.

\section{Evaluation Of Formulations:-}

Thickness Uniformity:-

The thickness of the patch was assessed by using Digimatic Micrometer (Mitutoyo, ABSOLUTE) at different points of the patch, from each formulation three randomly selected patches and the average wascalculated. The standard deviations of thickness were computed from the mean value ${ }^{10,11}$.

\section{Weight variation:-}

Weight variation should be studied by individually weighing 3 randomly selected patches. Such determination should be performed for each formulation.Patches from each batch were weighed individually and the average weight S.D. Determine was calculated ${ }^{10,11}$

\section{Drug Content Uniformity:-}

The patches at $\left(2 \times 2 \mathrm{~cm}^{2}\right)$, were cut and added to a beaker containing 100ml of Phosphate buffered solution of $\mathrm{pH}$ 7.4. To check the uniformity of the drug in the patch, three patches were taken out from each batch. Each Patch was then placed in volumetric flask containing $100 \mathrm{ml}$ of Phosphate buffered solution of $\mathrm{pH} 7.4$, and shaken to extract the drug from patch overnight period. One milliliter of above resulting solution was withdrawn, after suitable $10 \mathrm{ml}$ dilution with Phosphate buffered solution of $\mathrm{pH} 7.4$ and analyzed UV-spectrophotometrically at $374 \mathrm{~nm}$ using pH 7.4 Phosphate buffered solution . drug content of patches were calculated ${ }^{10,11}$. 


\section{Folding Endurance:-}

The folding endurance of the Patches was determined by repeatedly folding onePatch at the same place till it broke or folded up to 300 times, which is consideredsatisfactory to reveal good Patch properties. The number of times of Patch could befolded at the same place without breaking give the value of the folding endurance. This test was done on all the batches for three times ${ }^{11}$.

\section{Tensile Strength:-}

Tensile strength of the Patch was determined with "Texture analyzer" testing machine. Itconsists of two load cell grips. The lower one is fixed and upper one is movable. The test strip of specific size $\left(3 \mathrm{x} 1 \mathrm{~cm}^{2}\right)$ was fixed between these cellgrips and force was gradually applied till the patch breaks. The tensile strength of thePatch was taken directly from the dial reading. The tensile strength of Patchwas calculated by applying the following equation. Same procedure was repeated for three times and standard deviation was calculated from mean values ${ }^{11,12}$.

$$
\text { Tensile Strength }=\frac{\text { load at failure }}{\text { Area of Patch }} \times 100
$$

\section{Percentage Moisture Loss Test (Moisture content):-}

Percentage moisture loss was determined by keeping the Films $\left(2 \times 2 \mathrm{~cm}^{2}\right)$ ina desiccator containing anhydrous calcium chloride. After 3 days, the Films weretaken out, re-weighed and the percentage moisture loss was calculated using thefollowing formula ${ }^{11,12}$.

$$
\text { Percentage Moisture loss }=\frac{\text { Initial weight }- \text { Final weight }}{\text { Initial weight }} \times 100
$$

\section{Percentage Moisture uptake Test (Moisture uptake):-}

Percentage moisture uptake was determined by keeping the Films $\left(2 \times 2 \mathrm{~cm}^{2}\right)$ ina desiccator. A weighed film kept in desiccators at $40 \mathrm{C}$ for $24 \mathrm{~h}$ was taken out and exposed to saturated solution of potassium chloride in order to maintain $84 \% \mathrm{RH}$. After $24 \mathrm{hrs}$ the films are to be reweighed and determine the percentage moisture uptake from the below mentioned formula ${ }^{11,12}$.

$$
\text { Percentage Moisture Uptake }=\frac{\text { Final weight }- \text { Initial weight }}{\text { Initial weight }} \times 100
$$

\section{In Vitro drug releasestudy:-}

The diffusion studies were carried out to get an idea of permeation of drug through barrier from the transdermal system. The in vitro diffusion study was carried out with the cellophane membrane $(0.4 \mu)$ by using Franz diffusion cell. The cylinder consists of two chambers, the donor, and the receptor compartment. The donor compartment was open at the top and was exposed to atmosphere. The temperature was maintained at $32 \pm 0.5^{\circ} \mathrm{C}$ and receptor compartment was provided with sampling port. The diffusion medium used was phosphate buffer ( $\mathrm{pH} 7.4)$. In vitro drug releasestudywas performed by placing patch of known weight anddimension $\left(2 \times 2 \mathrm{~cm}^{2}\right)$ into small beaker containing $10 \mathrm{ml}$ of PBS pH 7.4. The beaker was placed on magnetic stirrer at $30 \mathrm{rpm}$. The samples were taken and the drug content was analyzed at $374 \mathrm{~nm}$ against reference standard using PBS pH 7.4 as a blank on a UV-visible spectrophotometer (Shimadzu Inc., Japan). Then immediately known amount of PBS pH 7.4 was added. The same procedure was repeated for three times.Result was plotted and tabulatedon the basis of In vitro release data. The volume of diffusion cell was $25 \mathrm{ml}$. The in vitro diffusion studywas carried out for 12 hours and $1 \mathrm{ml}$ sample waswithdrawn at an interval of 30min initially and then sample withdrawn after one hour interval for 12 hours. The same volume of phosphate buffer $\mathrm{pH} 7.4$ wasadded to receptor compartment to maintain sink conditionsand the samples were analyzed at $374 \mathrm{~nm}$ in UVspectrophotometer ${ }^{12,13}$.

\section{Stability Study:-}

Stability study was performed on F6 formulation, according to ICH guidelines by storing replicates of Patches (packaged in aluminium foil) in a humidity chamber, with a relative humidity a temperature of $40 \pm 0.5{ }^{\circ} \mathrm{C}$. At periodic intervals, the samples were taken out at $0,15,45$, and 90 days and the period for their degradation of the patch was checked. Samples were also analyzed for drug content ${ }^{14}$. 
Results and discussion:-

Solubility determination:

Table 2:-Solubility Determination

\begin{tabular}{|c|c|}
\hline Media & Saturation solubility(mg/ml) \\
\hline Water & 0.034231 \\
\hline $\mathbf{6 . 8 p H}$ & 0.079773 \\
\hline $\mathbf{7 . 4 P H}$ & 0.086312 \\
\hline
\end{tabular}

Drug-excipients compatibility studies:-

Fourier transform infrared spectroscopy(FTIR):-

Compatibility study was carried out by using FTIR and DSC by the use of drug \& excipients. The Individual IR spectra of pure drug and polymer as well as the combination spectra of the drug and polymer are shown in the figure 2 , which indicate no interaction between lornoxicam and polymers when compared with spectrum lornoxicam as all functional group frequencies were present.

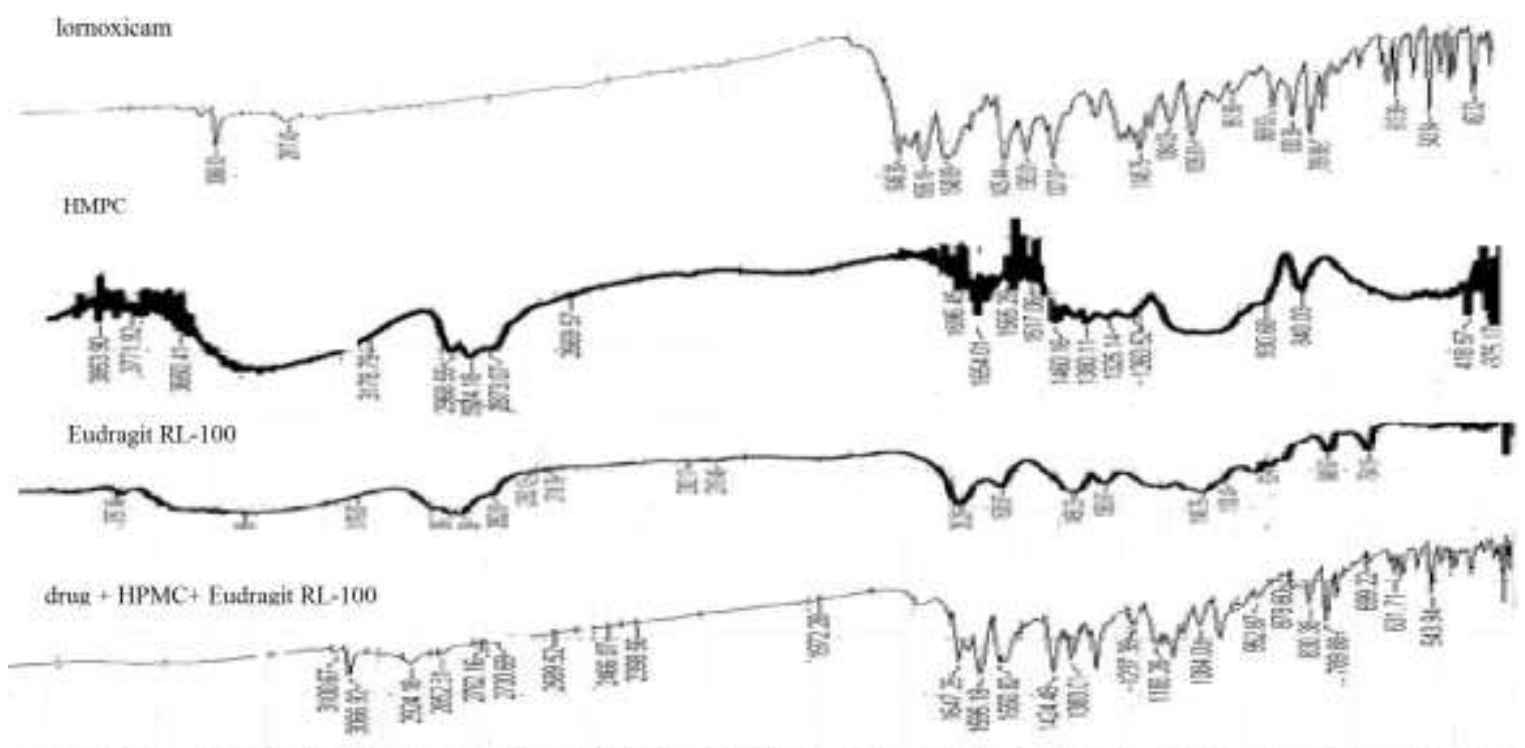

\section{$\begin{array}{lllllllllllllll}3750 & 3500 & 3250 & 3000 & 2750 & 2500 & 2250 & 2000 & 1750 & 1500 & 1250 & 1000 & 750 & 500\end{array}$}

Differential scanning calorimetry:-

The thermogram of lornoxicam exhibited exothermic peak at $224.65^{\circ} \mathrm{C}$ at then HPMC, Eudragit RL-100 shows endothermic peak between $205-210^{\circ} \mathrm{Cand} 260-265^{\circ} \mathrm{C}$. 


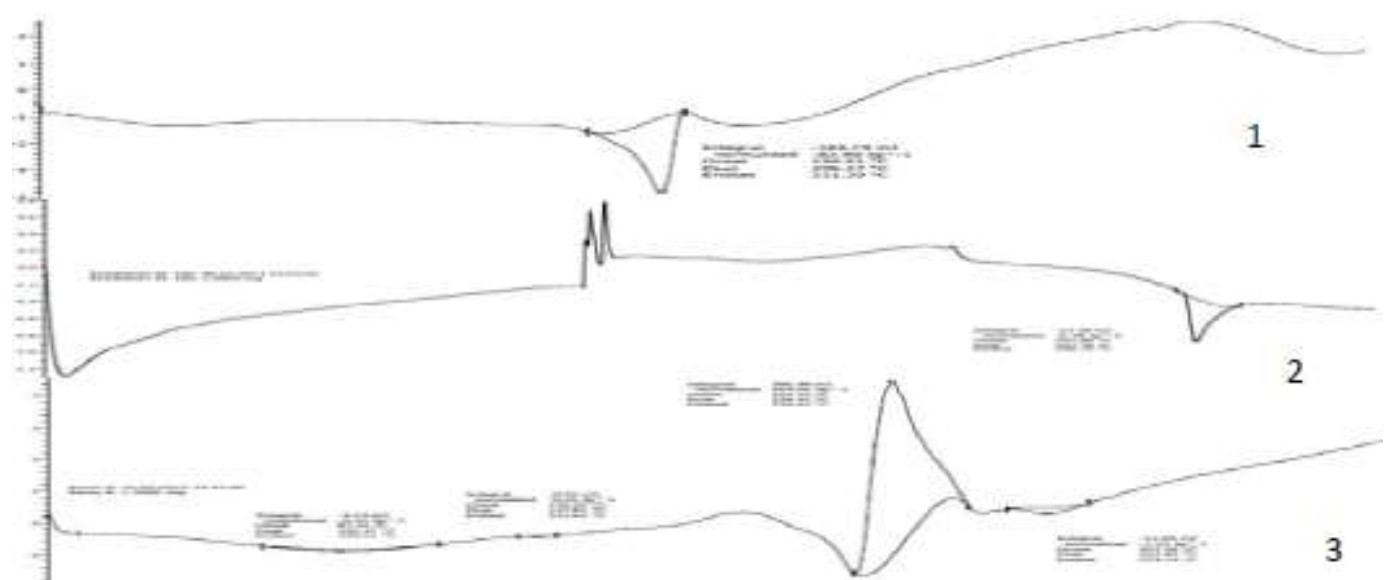

Fig 4:- dsc thermogram of 1. Hpmc 2. Eudragit rl-100 3. Formulation Evaluation parameter of prepared transdermal patches:

The prepared formulationswere evaluated for the given parameters.

1. Thickness Uniformity:

2. Weight variation

3. Drug Content Uniformity:

4. Folding Endurance:

5. Tensile Strength determination:

6. Percentage Moisture Loss Test (Moisture content):

7. Percentage Moisture uptake Test (Moisture uptake):

8. In vitro drug releasestudy:

9. Stability Study:

\section{Thickness Uniformity:-}

Thicknessesof drug-loaded patches were measured with the help of screw guage. Film thickness was found in the range $0.072 \pm 0.0447$ to $0.119 \pm 0.0537$. It means that the concentration of polymer does not show any significant change in the thickness of the film. The concentration of plasticizer did not alter the change in the thickness of patch. The mean values are shown in the table: 3 .

Table 3:-Data of Thickness determination of patches

\begin{tabular}{|c|c|}
\hline $\begin{array}{c}\text { Formulation } \\
\text { code }\end{array}$ & $\begin{array}{c}\text { Average thickness (mm) } \\
\text { AM } \pm \text { SD }\end{array}$ \\
\hline F1 & $0.119 \pm 0.0537$ \\
\hline F2 & $0.087 \pm 0.0382$ \\
\hline F3 & $0.093 \pm 0.0617$ \\
\hline F4 & $0.072 \pm 0.0447$ \\
\hline F5 & $0.103 \pm 0.0697$ \\
\hline F6 & $0.090 \pm 0.0595$ \\
\hline
\end{tabular}

\section{Weight variation:-}

The weight of the patch was found to be in the range of $0.193 \pm 0.032578$ to $0.342 \pm 0.04875 \mathrm{gm}$. Uniformity of the patches shows the good distribution of the excipients. As the Increasing polymer concentration weight of patch also increases. Shown in table 4.

Table 4:-Data of Weight uniformity of Patches

\begin{tabular}{|c|c|}
\hline $\begin{array}{ll}\text { Formulation } & \\
\text { code }\end{array}$ & $\begin{array}{c}\text { Average weight (gm) } \\
\text { AM } \pm \text { SD }\end{array}$ \\
\hline F1 & $0.193 \pm 0.032578$ \\
\hline $\mathrm{F} 2$ & $0.342 \pm 0.04875$ \\
\hline
\end{tabular}




\begin{tabular}{|l|l|}
\hline F3 & $0.225 \pm 0.020428$ \\
\hline F4 & $0.278 \pm 0.018009$ \\
\hline F5 & $0.204 \pm 0.025106$ \\
\hline F6 & $0.293 \pm 0.012288$ \\
\hline
\end{tabular}

Drug Content Uniformity:-

Drug content for varies formulation was found to be in the range of66.33 to 69.22 $\mathrm{mg}$ as shown in table no.5.

Table 5:-Drug content uniformity of patches

\begin{tabular}{|c|c|c|}
\hline $\begin{array}{c}\text { Patch } \\
\text { Code }\end{array}$ & $\begin{array}{c}\text { Amount of drug present } \\
(\mathbf{m g})\end{array}$ & $\begin{array}{c}\text { \% Drug present } \\
\text { AM } \pm \text { SD }\end{array}$ \\
\hline F1 & 66.33 & $92.13 \pm 0.84$ \\
\hline F2 & 67.86 & $94.26 \pm 1.0769$ \\
\hline F3 & 66.65 & $92.57 \pm 2.233$ \\
\hline F4 & 67.02 & $93.09 \pm 0.800$ \\
\hline F5 & 68.27 & $94.82 \pm 0.306$ \\
\hline F6 & 69.22 & $96.14 \pm 1.563$ \\
\hline
\end{tabular}

For the uniform dispersion of drug in patch, the drug content study was performed. The content uniformity of drugwas analyzed at $374 \mathrm{~nm}$ with a suitable blank. The results were expressed in $\mathrm{AM} \pm \mathrm{SD}$ and reported in table 5. The aforesaid values indicated that the drug was uniformly dispersed within the formulations.

\section{Folding endurance:-}

The folding endurance of the patch was found to be in the range of 195 to 389. The number of times the film could be folded at the same place without breaking gave the value of folding endurance. Folding endurance was found to be highest for F2 and lowest for F3 as shown in table 6. The change in the concentration of polymers and plasticizer did not show the difference in the folding endurance of patch. The value of folding endurance shows, the developed formulations exhibited good physical and mechanical properties.

Table 6:-Data of folding endurance of Patches

\begin{tabular}{|c|c|}
\hline $\begin{array}{c}\text { Formulation } \\
\text { code }\end{array}$ & $\begin{array}{c}\text { Average number } \\
\text { AM } \pm \text { SD }\end{array}$ \\
\hline F1 & $195.33 \pm 5.07$ \\
\hline F2 & $228.33 \pm 3.05$ \\
\hline F3 & $379.66 \pm 1.02$ \\
\hline F4 & $290.00 \pm 3.05$ \\
\hline F5 & $256.00 \pm 6.07$ \\
\hline F6 & $389.96 \pm 4.04$ \\
\hline
\end{tabular}

Tensile strength determination:-

The mechanical properties of patches were evaluated using a CT3 texture analyzer. The peak load was used to evaluate by the help of probe dual grip. The texture expert software recorded the data when the probe started withdrawing from the Patch. The peak load and the area under load distance curve obtained from the texture profile were used to assess the tensile strength of the Paches. The tensile strengths of drug loaded Patches are in the order of F2 > F1 > F3 > F4 > F5 > F6. Each measurement was repeated three times. The concentration of polymer and plasticizer shows higher effect on tensile strength of patch. When the concentration of HPMC increases accordingly then the tensile strength also increases. As per literature survey, the plasticizer shows effect on tensile strength see table 7.

Table 7:-Data of tensile strength of patches.

\begin{tabular}{|c|c|}
\hline $\begin{array}{c}\text { Formulation } \\
\text { code }\end{array}$ & $\begin{array}{c}\text { Tensile strength }(\mathbf{k g}) \\
\text { AM } \pm \text { SD }\end{array}$ \\
\hline F1 & $1.55 \pm 0.35$ \\
\hline
\end{tabular}




\begin{tabular}{|l|l|}
\hline F2 & $1.15 \pm 0.16$ \\
\hline F3 & $0.41 \pm 0.55$ \\
\hline F4 & $0.73 \pm 0.55$ \\
\hline F5 & $1.29 \pm 0.28$ \\
\hline F6 & $1.63 \pm 0.39$ \\
\hline
\end{tabular}

Percent moisture absorption (Moisture content):-

Moisture content was found to be in the range of $2.252 \pm 0.90$ to $7.151 \pm 1.44 \mathrm{mg}$. Moisture content was determined by keeping the patches in a desiccator containing calcium chloride for $24 \mathrm{hr}$. Percentage moisture content was calculated from the weight differences relative to the final weight. Results of moisture content study are shown in table 8 and fig. 5. Moisture content was found to be increasing with increasing concentration of hydrophilic polymer i.e. ERL-100.

Table 8:-Percentage Moisture loss (Moisture content) of Patches.

\begin{tabular}{|c|c|}
\hline Formulation (mg) code & $\begin{array}{c}\text { Average weight } \\
\text { AM } \pm \text { SD }\end{array}$ \\
\hline F1 & $4.777 \pm 1.05$ \\
\hline F2 & $4.097 \pm 0.70$ \\
\hline F3 & $5.663 \pm 1.39$ \\
\hline F4 & $7.151 \pm 1.44$ \\
\hline F5 & $3.770 \pm 0.81$ \\
\hline F6 & $2.252 \pm 0.90$ \\
\hline
\end{tabular}

\% Moisture content

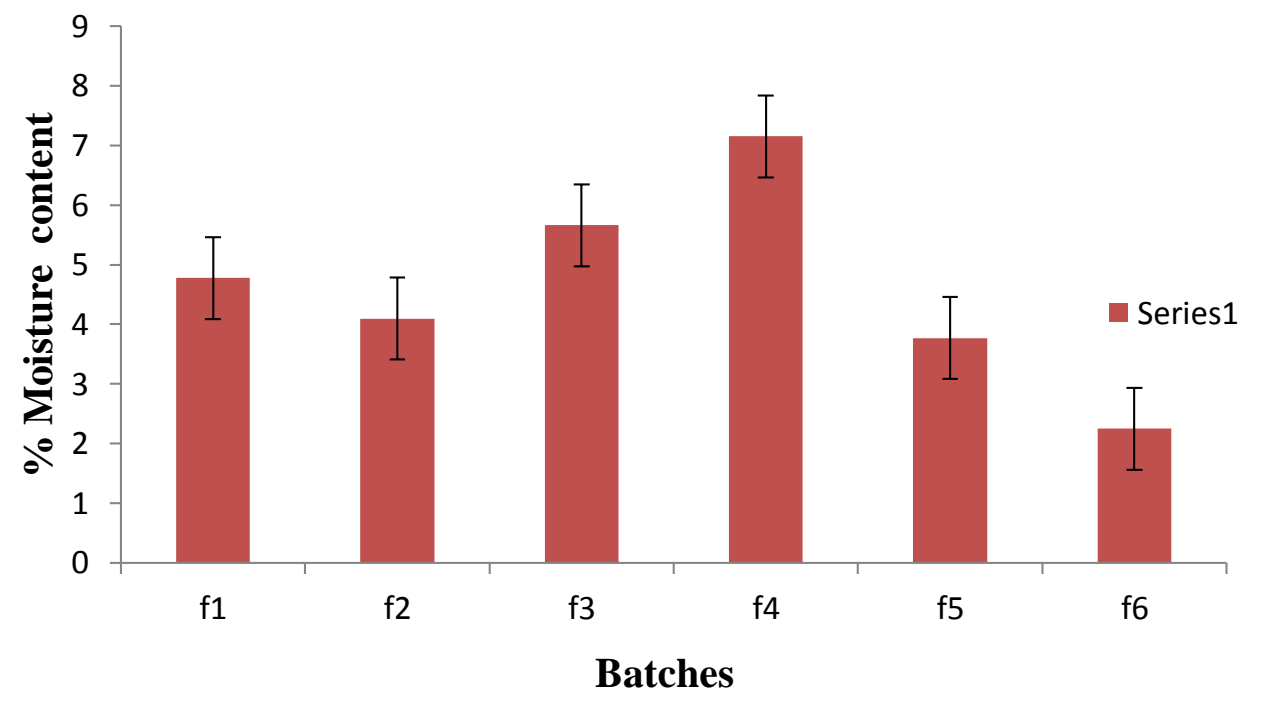

Fig 5:-Percentage Moisture Content

Moisture content in the patches were found to be low, low moisture content helps them to remain stable and from being completely dried and brittle. The capacity of the Patch to take up water is an intrinsic parameter of the polymeric system in consideration to the release of drug.

\section{Percentage Moisture uptake Test: (Moisture uptake):-}

Moisture uptake of the patch was found to be in the range of $2.158 \pm 0.31$ to $7.211 \pm 1.26 \mathrm{mg}$. The percentage of moisture uptake was calculated as the difference between final and initial weight with respect to initial weight. The Patches were exposed to relative humidity of $75 \%$ (Saturated solution of sodium chloride) at room temperature. The results of moisture content studies are shown in table 9 and Fig.6. Low moisture uptake protects the patch from microbial contamination and bulkiness. 
Table 9:-Data of Percentage Moisture uptake of Patches.

\begin{tabular}{|c|c|}
\hline $\begin{array}{c}\text { Formulation } \\
\text { code }\end{array}$ & $\begin{array}{c}\text { Moisture uptake wt. (mg) } \\
\text { AM } \pm \text { SD }\end{array}$ \\
\hline F1 & $7.211 \pm 1.26$ \\
\hline F2 & $2.158 \pm 0.31$ \\
\hline F3 & $4.501 \pm 1.53$ \\
\hline F4 & $6.150 \pm 2.14$ \\
\hline F5 & $5.466 \pm 1.33$ \\
\hline F6 & $2.649 \pm 1.17$ \\
\hline
\end{tabular}

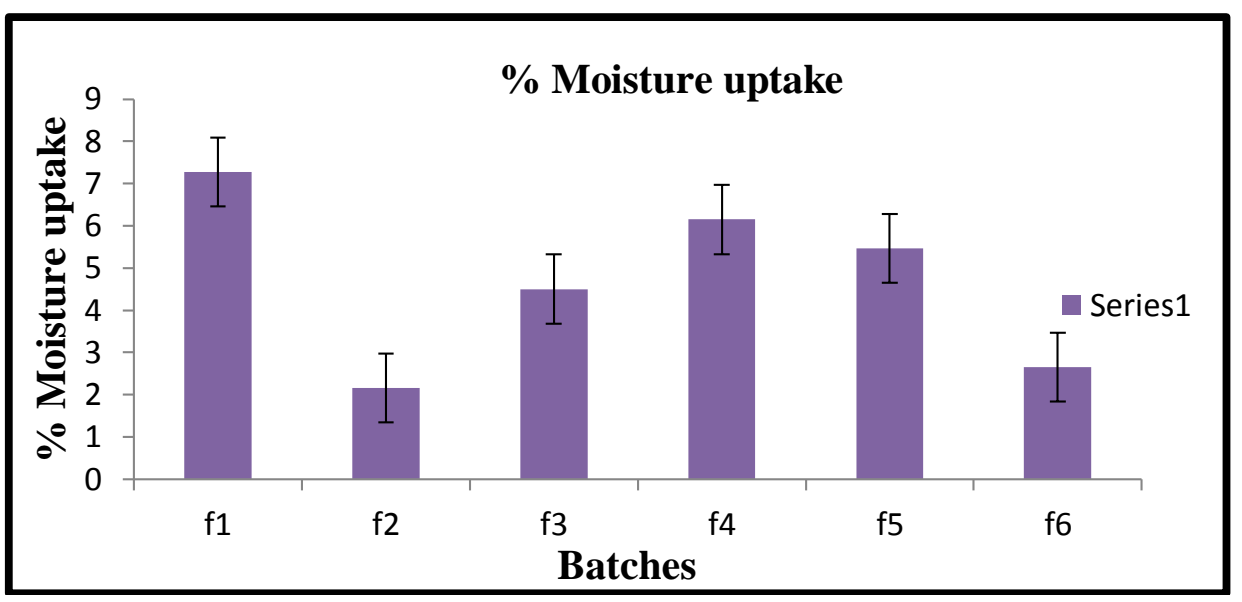

Fig 6:-Percentage Moisture Uptake

Invitro drug release study:Cumulative in-vitro drug release study was performed in PBS pH 7.4 \& their data is given in fig.7.

The in-vitro drug release profile is an important tool that predicts in advance how a drug will diffuse and targeted. The results of in-vitro permeation studies of lornoxicam from transdermal patches are shown in table 19. In the present study, hydrophilic (HPMC) and hydrophobic (ERL-100) polymers are used to prepared patches. Formulation F6 exhibited $96.74 \pm 5.4 \%$ of drug release value, while formulation F1 exhibit $76.65 \pm 3.3 \%$ of drug release value. The cumulative amount of drug released from formulations containing hydrophilic polymer show release of drug at faster rate than hydrophobic polymer.

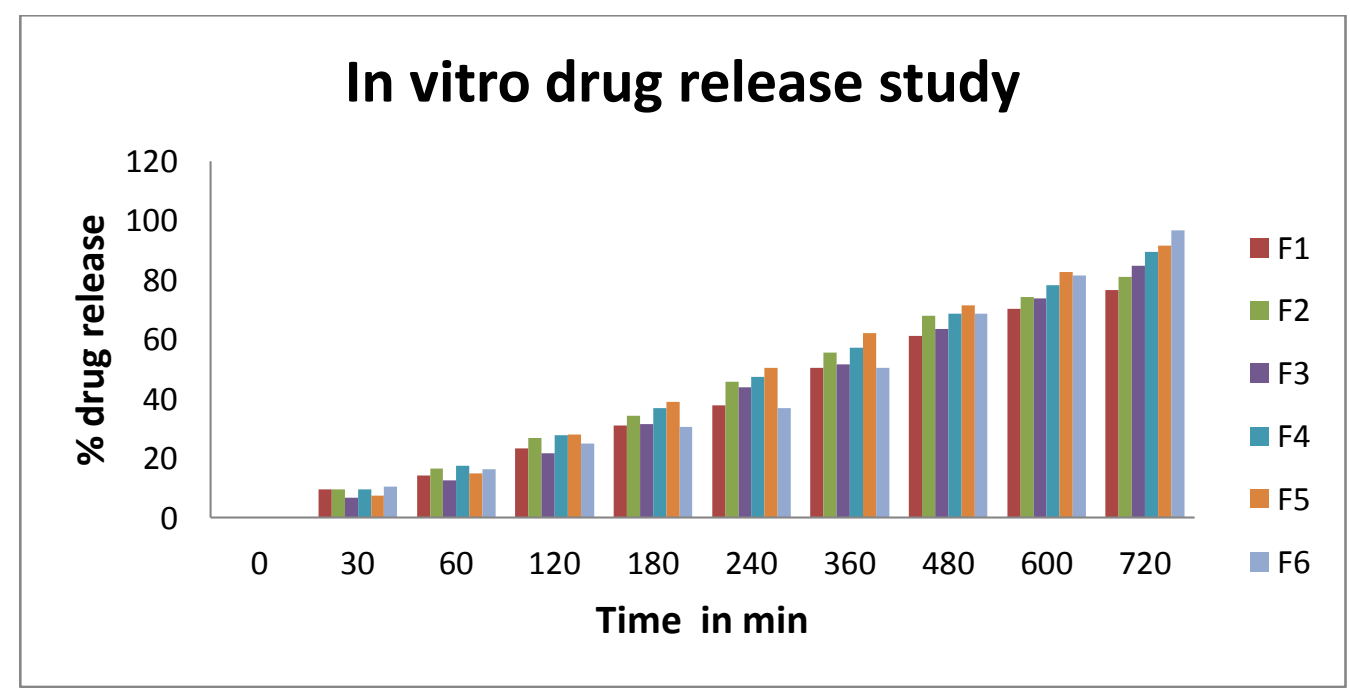

Figure 7:-In- Vitro Drug Release Study Of Formulation F1-F6 
In vitro drug release study indicated that the release of drug varied from the formulation batches according to their type and concentration of polymers utilized. Asprepared the concentration of Eudragit RL-100 was increases gradually the release of drug was decreased. The concentration of HPMC was increases the drug release showed effect increases release amount of drug. The variation of plasticizer in different formulation shows effect on release of drug. Polyethylene glycol plasticizer incorporated patches shows better drug release as compared to the Dibutylphthalate the formulation F1, F3, F5 shows decreased in release rate because formulation without containing PEG400 plasticizer.

The F5 batch shows sustainly drug release $92.43 \pm 2.5$ but as compared to that batch F6, higher cumulative $96.74 \pm$ $5.4 \%$ in vitro release was observed which contained 100mg . Hydroxy propyl cellulose and 200mg Eudragit RL-100 (1:2) ratio which shows effect as increases amount of release of drug in 12 hours. The 5\% of plasticizer concentration shows increase amount of release of drug. The drug release from the patch is ordered as F6 > F5 > F4 $>\mathrm{F} 2>\mathrm{F} 3>\mathrm{F} 1$.

\section{Stability Study of optimized formulation:-}

Accelerated Stability study was carried out for optimized formulation at $40^{\circ} \mathrm{C}$ temperature in a humidity chamber having $75 \%$ RH \& were carried outfor as per the ICH guidelines. After 3 months, at periodic interval, samples were withdrawn; the formulation was evaluated for physicochemical properties drug content and in vitro drug release study. Results are showed in table 20 , no major differences was found between evaluated parameters before and after ageing/storing and all were found to be in acceptable limits.Based on the results of initial characterization batch F6 were thought to be the superior formulation and hence further subjected to accelerated stability study for 3 months.

Table 10:-Evaluation parameters of stability batch (F6)

\begin{tabular}{|c|c|c|c|c|}
\hline Evaluation parameters & $\begin{array}{c}\text { Before } \\
\text { stabilityStorage }\end{array}$ & $\begin{array}{c}\text { After 15days } \\
\text { storage }\end{array}$ & $\begin{array}{c}\text { After 45 days } \\
\text { storage }\end{array}$ & $\begin{array}{c}\text { After 90 } \\
\text { days } \\
\text { Storage }\end{array}$ \\
\hline Drug content (\%) & $96.14 \%$ & $94 \%$ & $95.34 \%$ & $97.63 \%$ \\
\hline $\begin{array}{c}\text { Percent drug dissolve in 7.4 pH } \\
\text { phosphate buffer }\end{array}$ & $92.441 \%$ & $91.569 \%$ & $88.849 \%$ & $91.667 \%$ \\
\hline
\end{tabular}

There was no significant decrease in drug release and drug content rate of formulation F6 over the period of 3 months.

\section{References:-}

1. Balfour JA, Fitton, A, Barradell, LB. Lornoxicam: A review of its pharmacology and therapeutic potential in the management of painful and inflammatory conditions Drugs. Adv Drug Del Rev 2013; 51:639-57.

2. Prausnitz MR, Mitragotri S, Langer R. Current status, and future potential of transdermal drug delivery. Nat Rev Drug Discovery $2004 ; 3(2): 115-24$.

3. Ryan DG, Peterson TA. Myths about transdermal drug delivery. Drug Delivery Tech 2003; 3(4):1-7.

4. Langer R. Transdermal drug delivery: past progress, Current status and future prospects. Adv Drug Del Rev 2004; 56 (5):557-8.

5. Buritova J, Besson JM. Dose-related anti-inflammatory/analgesic effects of lornoxicam: a spinal c-Fos protein study in the rat. Inflamm Res 1998; 47:18-25.

6. Baria A, Patel RP, Patel G. Formulation and evaluation of transdermal patch of Aceclofenac.Int J Drug Delivery 2009; 1:41-51.

7. Mandal S. Formulation and evaluation of carvedilol transdermal patches. Int Res J Pharm2011; 2(1):237-48.

8. Benson, HAE. Transdermal drug delivery: Penetration enhancement techniques. Curr. Drug Delive 2005; 2:2333.

9. Patel, KN, Patel, HK, Patel, VA, , "Formulation and Characterization of drug in adhesive transdermal patches of diclofenac acid", Int Journal of Pharma and Pharma Scie. 2012; 4 (1):296-299.

10. Mao Z, Zhan X, Tang G, Chen S, 'A new copolymer membrane controlling clonidine linear release in a transdermal drug delivery system'. Int J Pharm; 2006;1(5) :332

11. Parthasarathy G, Reddy B, Prasanth VV. Formulation and Characterization of transdermal patches of Naproxen with various polymers. 2011; 6 (07). 
12. Siepmann J, Peppas NA. Modeling of drug release from delivery systems based on hydroxypropyl methylcellulose. Adv Drug Delivery Reviews 2001;2(3):139-157.

13. Pruss TP, Stroissnig H, Radhofer-Welte S, Wendtland W, Mehdi N, Takacs F, Fellier H. Overview of the pharmacological properties, pharmacokinetics, and animal safety assessment of lornoxicam .Postgrad Med J66, 1990;4: 18-21

14. Keleb E, Sharma R, Mosa EB, Zaljahwi AZ. Transdermal drug delivery system- design and evaluation.Int J Adv Pharma Sci, 2010; 1: 201-211. 